\title{
News From the TOS Council
}

\author{
By Melbourne G. Briscoe
}

$T_{1}$ HE TOS COUNCIL met June $2-3$ in Washington DC. at the AMS/TOS Washington office. July 19 and 22 in Honolulu at the TOS Pacific Basin Meeting. and October 13-14 in Norfolk. VA, at Old Dominion University. Present at all or some of these meetings were Arnold Gordon (as President, and then PastPresident). Margaret Leinen (as President-Elect, then President). Bob Duce (new President-Elect). Judi Rhodes (Executive Director). Mel Briscoe (Secretary), Larry Atkinson (Oceanography editor). Anne West-Valle (Oceanography editorial assistant). Bob Anderson. Dick Barber. Steve Calvert. Dave Evans. Connie Sancetta. and Rick Spinrad.

In addition to formal meetings, a remarkable amount of Council business is conducted on electronic mail. originally Omnet but now exclusively on the Internet. Members may reach the TOS Council using the mailing list tos-council a ccpo.odu.edu. Non-Council business, for example membership or meeting information, should be conducted directly with Judi Rhodes at jrhodes @ ccpo.odu.edu.

The Council tends to focus on three major areas:

- Business Affairs of the Society thinances. committees. elections. membership. etc):

- Member Services fcommunications. including meetings. Oceanography. electronic information distribution. and ocean community activities, such as awards and letters supporting ocean sciences positions on various issues like DoD appropriations. IAPSOILGG arguments: and

- Strategic Planning coonstituency and priorities. membership development. current and future TOS mission and focus).

\section{Business Affairs}

TOS finances and membership are stable but not robust. TOS has about 1,200 regular members, 325 life members, 300 student members, 10 corporate members. and 116 library (Oceanography subscription) members. About 225 of the members are from outside the U.S.: it is the goal of the Council to see a strong growth in the non-U.S. membership of our international society.

The annual TOS budget is about $\$ 300.000$. with dues and subscriptions to Oceanography accounting for about a quarter of the income. The dues income is not quite enough to pay for Oceanography. much less other overhead expenses like the salary of the Executive Director. or email. The rest of the budget is completely dominated by meeting income and expenses. This is typical of scientific societies: the health of the budget is proportional to the health of its meetings: you don t make money on membership dues or publications. Were it not for a slight profit on our meetings, TOS would not he able to stay in business.

Unfortunately for the TOS financial picture, the TOS biennial meeting style of no parallel sessions limits the possible income from abstracts and presenters. Take a look at the AGU Fall Annual Meeting abstracts hook. and work out what it means at $\$ 50$ per abstract. and how little it costs to produce the book from camera-ready cop!. TOS was formed in 1988 . in part. 10 provide an ocean sciences forum that was an altermative to the $A G L^{\circ}$ masive meeting and endless parallel sessions of short. often poorly given talk. We feel we have vaceeded spectacularly with our meetings formal. but we also know we suffer the tinancial consequences.

The business of the Society hat groun. so that the Council can no longer look after all aspects itself. and make all the decisions. We are furming a Mamhership Committee a Publication Committee. and a Meetings Committee (Chair: Eric Hartwig. Naval Research Lab) in addition to the Nominations Committee (Chair: Steve Calvert. University of British Columbia) already in place. Any TOS members who wish to participate in the work of these committees should contact the Council or the Chair of the committee directly.

The business affairs of the Society are the underpinning to the services to members: our Council meetings tend to contain many good ideas for ways TOS could help its members and be an increasingly potent force in the ocean sciences community. but most of these ideas take time and money to implement: time and money are related to the size of our membership and the strength of our meetings. which are in turn related to the quality and visibility of our member services, and thus to our finances. and so on. The strategic planning described below is designed to find the balance point and leverage in this "viscous" circle.

\section{Nember Services}

Foremost among our services is the world-class magazine. Oceanography. First edited by Date Brooks, and then by Chuck Nittrouer. it now has Larry Atkinson at the helm. With the assistance of Anne West-Valle. Its publication schedule is 3 times a year. with hope for increasing to 4 . then 6 times per year. The obuticles are production cost, the additional editorial and protessional time required, and volume of material being submitted. Although the material that is ubmitled and published in Oceanography is broally interesting and of high quality. there are not many submissions. Tuning the magazine to the neads of the TOS membership is a main task for the new Publication. Committee.

Oicumoraphy may hecome quarterly. but there is need for communication of rean science new and information on a much more timely basis. The council has discussed for several years the possibility 
of a newsletter. at least monthly, perhaps bi-weekly. Production and mailing costs turn out to be prohibitive for a society our size. Electronic distribution via Omnet was considered, but felt at the time to be exclusionary to those without Omnet subscriptions. (Now, of course. we are all without Omnet.) Providing an electronic newsletter by the Internet has been a recent discussion, but two obstacles have confronted us: who is to be the editor/champion of the electronic newsletter. and what about those who do not have Internet access? We have investigated some existing newsletters: the main problem always seems to be getting material submitted for the newsletter. Internet access is not universal. particularly outside the U.S.: since we are an international society, the Council does not wish to produce a U.S.-centric publication. We are optimistic that Internet access will grow, and that we will find a newsletter editor. Any volunteers?

The demise of Omnet concerns us deeply. The ocean sciences have been remarkably cohesive, internationally. largely because our common interest in the global ocean has been supported and aided by the global communications of Omnet. It is hard to give too much emphasis to what has been the unique nature of communications among ocean scientists; ships, oceans. and time zones were no bounds to our exchange of information. The TOS Council wishes to help the community regain and strengthen its global sense of collaboration. We have contacted the major ocean agencies in the U.S. to see if they will help us do this. The Publications Committee will have the responsibility to develop our electronic communication plans. Meanwhile in a modest effort we are cooperating with the USGOOS interagency project office to maintain an e-mail directory. More information on this will be available later.

Meetings are important. We need enough of them to keep the communication flowing. but not so many as to burden the community with travel and presentations and the attendant costs. We started with a biennial meeting, in the spring, on the off-year (odd-numbered years) from the AGU Ocean Sciences Meeting (evennumbered years). Our goal was to provide an alternative format. as mentioned above. By all reports. we have met our goal. In 1994. we experimented with the Pacific
Basin Meeting. a single-topic. focussed scientific meeting. Our new Meetings Committee has the task of looking at the membership needs versus what TOS can afford to support. and making recommendations about both regular (biennial) and special meetings. The biennial meetings have been in Monterey (1989). St. Petersburg (1991), and Seattle 1993). We are looking forward to Newport. RI in 1995. and will return to Seattle in 1997. We intend to sponsor a focussed scientific meeting in Europe in 1996. working with the International Council of Scientitic Unions (ICSL) and with various European ocean groups: our goal is to help be a unifying influence for European oceanography, and to concentrate on the international interfaces between the large programs. for example IGBP and LOICZ. WCRP and JGOFS. and WOCE and GCOS/GOOS. The recent agreement for EuroGOOS may help in this goal.

TOS and the U.S. Nary (Office of the Oceanographer. and the Office of Naval Research) sponsor the Walter Munk Award. so far given to Munk (the naming ceremony for the Medal) and to David Farmer from the IOS. BC Canada. There are many important activities in the ocean sciences that probably ought to be noted and recognized: the Council has discussed other awards for scientitic and technical achievement in various topical areas. and for service to the educational. infrastructure. and other nonresearch parts of the profession. There is no Awards Committee: if you provide input on this topic it should go directly to the Council.

Issues arise that need community vetting and action. A recent example is the $50 \%$ cut proposed in U.S. DoD funding of university research: this would have directly and seriously affected the Office of Naval Research programs both in the U.S. and abroad. TOS provided one of the hundreds of letters that went to Congress to argue the folly of such a cut. especially in the ocean sciences: this was done on short notice by the TOS Council on your behalf. Although a $10{ }^{\circ} c$ cut was finally sustained in the FY95 funding. Congressional staffs have reported that the thoughtful and unprecedented number of letters that arrived were responsible for the reduction from $50 \mathrm{r}$, proposed to $10^{\circ} \mathrm{C}$ actual. As another example. TOS was asked by IAPSO to cosponsor the IAPSO sessions to take place in August 1995 in
Honolulu. After spirited debate, the TOS Council choose to send IAPSO a letter cosponsoring any IAPSO sessions that take place at the IUGG General Assembly in Boulder in July. at which time and place IAPSO was originally sheduled to meet. Our point was that we stand tirmly behind interdisciplinary oceanography. and the interfaces between oceanography and other disciplines. hence our cosponsoring interest is much greater for the ILGG than for IAPSO alone.

\section{Strategic Planning}

Under Margaret Lienen's leadership. we have embarked on a strategic planning process to look broadly at membership. services, focus, and finances. The permanent committees formed and being formed are a result of this process.

One major aspect of the planning has been to look at the various ocean constituencies that TOS serves or could serve. The current constituency is primarily the U.S. academic research community. After discussion. it has been agreed to concentrate on research during Margaret Leinen's presidency /in and out of universities. including both those who do and those who administer (or manage, research| and international oceanographers: Bob Duce"s agenda for the following two-year period is to increase our membership and participation of graduate students and nonresearch professionals le.g.. applied oceanographers in government and industry). For later assignments. we will address nonuniversity educators llike K-l I and community collegess, then those in public policy, and tinally the public itself.

One motivation for this strategy is 6 build on and enhance the strengths and community we already have. then to buttress that community with its source pool (graduate students) and its working partners who are not researchers. It is not that we see educators. public policy. and the public as lowest priority. but rather as lowest urgency for membership and services development. As anyone who attended the Pacific Basin Meeting in Honolulu can attest. We feel strongly about the importance to oceanography of understanding and contributing to public policy discussions and decisions: we will continue to emphasize public policy in our meetings and communications. We will attempt to address those policy issues that 
are not uniyue to one nation, such as govermmental support for ocean science and how oceanography can be made useful to the public. However, such discussions can quickly become national when the details arise. Your help is needed so that we strike the right balance between U.S. policy matters and those that are more international. TOS membership input to the discussion is probably the best checkand-balance.

In the spirit of treating the TOS membership as its customers. the Council would like to invite and encourage its membership to participate in this ongoing strategic planning process. Your input can come to us through any medium. at any time, because the process will continue. Letters to the Editor of Occanography are one way to raise an issue: email to the Council is another. Future versions of this Council Report will appear in Oceanography; they will be shorter, because they will cover fewer Council meetings, and we would like to see them reflect your input and concerns. 